\title{
ANTIMYCOBACTERIAL AND CYTOTOXICITY ACTIVITY OF SYNTHETIC AND NATURAL COMPOUNDS
}

\section{Ana O. de Souza*}

Laboratório de Bioquímica e Biofísica, Instituto Butantan, Av. Vital Brasil, 1500, 05503-900 São Paulo - SP, Brazil

Fabio C. S. Galetti and Célio L. Silva

Departamento de Bioquímica e Imunologia, Faculdade de Medicina de Ribeirão Preto, Universidade de São Paulo, 14040-901 Ribeirão Preto - SP, Brazil

Beatriz Bicalho, Márcia M. Parma, Sebastião F. Fonseca and Anita J. Marsaioli

Departamento de Química Orgânica, Instituto de Química, Universidade Estadual de Campinas, 13084-971 Campinas - SP, Brazil

Angela C. L. B. Trindade and Rossimíriam P. Freitas Gil

Departamento de Química, Universidade Federal de Minas Gerais, 31270-901 Belo Horizonte - MG, Brazil

Franciglauber S. Bezerra, Manoel Andrade-Neto and Maria C. F. de Oliveira

Departamento de Química Orgânica e Inorgânica, Universidade Federal do Ceará, 60451-970 Fortaleza - CE, Brazil

Recebido em 13/7/06; aceito em 10/4/07; publicado na web em 5/10/07

\begin{abstract}
Antimycobacterial and cytotoxicity activity of synthetic and natural compounds. Secondary metabolites from Curvularia eragrostidis and Drechslera dematioidea, Clusia sp. floral resin, alkaloids from Pilocarpus alatus, salicylideneanilines, piperidine amides, the amine 1-cinnamylpiperazine and chiral pyridinium salts were assayed on Mycobacterium tuberculosis H37Rv. N-(salicylidene)-2hydroxyaniline was the most effective compound with a minimal inhibitory concentration (MIC) of $8 \mu \mathrm{mol} / \mathrm{L}$. Dihydrocurvularin was moderately effective with a MIC of $40 \mu \mathrm{mol} / \mathrm{L}$. Clusia sp. floral resin and a gallocatechin-epigallocatechin mixture showed MIC of $0.02 \mathrm{~g} / \mathrm{L}$ and $38 \mu \mathrm{mol} / \mathrm{L}$, respectively. The cytotoxicity was evaluated for $\mathrm{N}$-(salicylidene)-2-hydroxyaniline, curvularin, dihydrocurvularin and Clusia sp. floral resin, and the selectivity indexes were $>125,0.47,0.75$ and 5, respectively.
\end{abstract}

Keywords: antimycobacterial activity; natural products; synthetic products.

\section{INTRODUCTION}

After AIDS, tuberculosis (TB) is the leading cause of infectious disease mortality in the world entering the $21^{\text {st }}$ century. The emergence of multi-drug resistant Mycobacterium tuberculosis strains is a contributing factor to the urgent need for new and more effective antimycobacterial drugs. In this context, many groups are fully committed to finding good active drugs that kill bacilli with low toxicity to mammalians ${ }^{1}$.

One of the oldest and most effective strategies to discover and develop new chemotherapeutics is to conduct bioassays of the crude extract of natural products before isolating and evaluating its chemical components. Secondary metabolites from plants and microorganisms represent a large source of compounds endowed with ingenious structures and potent biological activities. Many of the products currently used on humans or for animal therapy in animal husbandry and in agriculture are produced by microbial fermentation or derived from the chemical modification of a natural product ${ }^{2}$.

In the field of synthetic chemistry, numerous studies of the synthesis and antimicrobial characteristics of quaternary ammonium compounds have been conducted since 1935. Among these compounds, pyridinium salts represent an important group of chemicals widely used as biocides, cationic surfactants, drugs and herbicides. Disinfectants based on this class are widely used in hospital environments and in the food industry due to their low toxicity to humans and animals and to their wide antimicrobial spectra $^{3}$. A class of functionalized cationic surfactants showed

*e-mail: olivia@butantan.gov.br antimicrobial activity with some exhibiting strong activities over wide antibacterial spectra similar to the activity of benzalkonium chlorides ${ }^{4}$.

This study, in a continuing effort to seek effective antimycobacterial substances ${ }^{5-7}$, reports the determination of the minimal inhibitory concentration (MIC) for M. tuberculosis H37Rv of a diverse group of compounds, including $\mathrm{N}$-(salicylidene)-4-toluidine (1), N-(salicylidene)-2-hydroxyaniline (2), N-(salicylidene)-4aminobenzoic acid (3), $\mathrm{N}$-(salicylidene)-4-nitroaniline (4), dihydrobenzoxazine (5), piperidine amides (6-7), the amine 1cinnamylpiperazine (8), a series of chiral pyridinium salts (16-23), major secondary metabolites from filamentous fungi such as Curvularia eragrostidis and Drechslera dematioidea, benzophenone rich floral resin of Clusia sp., and major alkaloids from Pilocarpus species (24-31). Cellular viability was evaluated for $\mathrm{N}$-(salicylidene)2-hydroxyaniline (2), curvularin (28), dihydrocurvularin (29) and Clusia sp. floral resin.

\section{EXPERIMENTAL}

\section{Synthetic compounds}

Salicylideneanilines, piperidine amides and amines

The N-(salicylidene)-4-toluidine (1), N-(salicylidene)-2hydroxyaniline (2), $\mathrm{N}$-(salicylidene)-4-aminobenzoic acid (3) and $\mathrm{N}$-(salicylidene)-4-nitroaniline (4) were prepared according to Iskander and Andrews ${ }^{8}$, Zheglova et al. ${ }^{9}$, Senier and Shepeard ${ }^{10}$, and Katritsky et al. ${ }^{11}$, respectively. The dihydrobenzoxazine (5) was prepared according to Iskander and Andrews ${ }^{8}$. The amides 3,4methylenedioxycinnamoylpiperidine (6) and 3,4-methylenedioxy- 
benzoylpiperidine (7) were obtained through standard procedures ${ }^{12}$ and the amine 1-cinnamylpiperazine $(\mathbf{8})$ was purchased from Isochem (Figure 1).
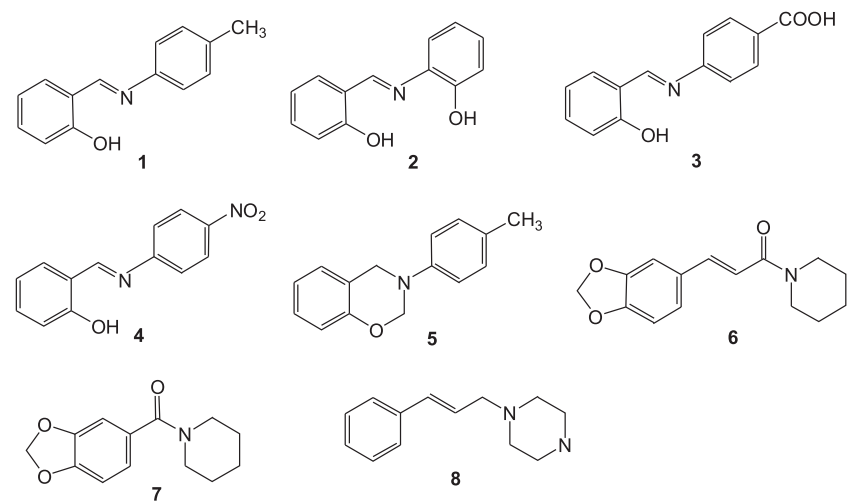

Figure 1. Structures of synthetic compounds evaluated on $M$. tuberculosis H37Rv: N-(salicylidene)-4-toluidine (1), N-(salicylidene)-2-hydroxyaniline (2), $N$-(salicylidene)-4-aminobenzoic acid (3), N-(salicylidene)-4-nitroaniline (4), dihydrobenzoxazine (5), 3,4-methylenedioxycinnamoylpiperidine (6), 3,4methylenedioxybenzoylpiperidine (7) and 1-cinnamylpiperazine (8)

\section{Pyridinium salts}

Chiral pyridinium salts (16-23) were prepared via Zincke's reaction ${ }^{13}$ as outlined in Scheme 1. The Zincke's salts (13), (14) and (15) were easily prepared via a reaction of commercially available pyridine (9), 3-picoline (10), and 3-ethylpyridine (11), respectively, with 1-chloro-2,4-dinitro-benzene (12) under acetone reflux over $15 \mathrm{~h}$. The treatment of these salts in an equimolar ratio with selected chiral primary amines in butanol reflux overnight furnished the corresponding chiral pyridinium salts. The reaction proceeded without racemization and the salts were isolated as viscous oils with yields of at least $80 \%$ after chromatography on silica gel. The salt (22) was prepared by treatment of (21) with sodium dodecyl sulphate in dichloromethane under reflux for 3 hours followed by filtration (Scheme 1).

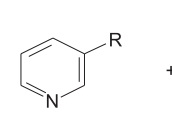

$9 \quad \mathrm{R}=\mathrm{H}$ $10 \mathrm{R}=\mathrm{CH}_{2} \mathrm{CH}_{3}$ $11 \mathrm{R}=\mathrm{CH}_{3}$<smiles>O=[N+]([O-])c1ccc(Cl)c([N+](=O)[O-])c1</smiles><smiles>[R]c1ccc[n+](-c2ccc([N+](=O)[O-])cc2[N+](=O)[O-])c1</smiles>

$13 \mathrm{R}=\mathrm{H}$ $14 \mathrm{R}=\mathrm{CH}_{2} \mathrm{CH}_{3}$ $15 \mathrm{R}=\mathrm{CH}_{3}$

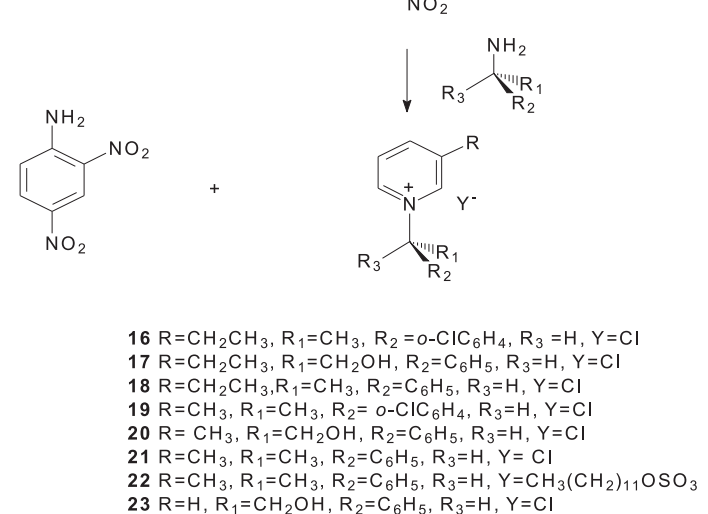

Scheme 1. Synthesis of chiral pyridinium salts evaluated on M. tuberculosis H37Rv

\section{Physical chemical characterization}

Synthesized and isolated compounds were characterized through physical chemical analysis such as ${ }^{1} \mathrm{H}$ and ${ }^{13} \mathrm{C}$ nuclear magnetic resonance (NMR), mass spectrometry and infrared spectra, and the data are in agreement with the literature for the $\mathrm{N}$-(salicylidene)-4toluidine $(\mathbf{1})^{8}, \mathrm{~N}$-(salicylidene)-2-hydroxyaniline $(\mathbf{2})^{9}, \mathrm{~N}$-(salicylidene)4-aminobenzoic acid (3) ${ }^{10}, \mathrm{~N}$-(salicylidene)-4-nitroaniline $(\mathbf{4})^{11}$, dihydrobenzoxazine $(5)^{8}, 3,4$-methylenedioxycinnamoylpiperidine $(\mathbf{6})^{12}$, 3,4-methylenedioxybenzoylpiperidine (7) ${ }^{12}, 1-\left(2^{\prime}, 4^{\prime}\right.$-dinitrophenyl)pyridinium chloride (13) $)^{14}, 1$-(2',4'-dinitrophenyl)-3-ethylpyridinium chloride (14) ${ }^{14}, 1$-(2',4'-dinitrophenyl)-3-methylpyridinium chloride (15) ${ }^{13},(R)-(-)-1-(2$ '-hydroxy-1'-phenylethyl)-3-ethylpyridinium chloride $(\mathbf{1 7})^{14},(S)-(-)-1-\left(1^{\prime}\right.$-phenylethyl)-3-ethylpyridinium chloride $(\mathbf{1 8})^{13},(R)$ (-)-1-(2'-hydroxy-1'-phenylethyl)-3-methylpyridinium chloride $(\mathbf{2 0})^{13}$, $(S)-(-)-1-\left(1^{\prime}-\right.$ phenylethyl)-3-methylpyridinium chloride $(\mathbf{2 1})^{15}$, and $(R)$ (-)-1-(2'-hydroxy-1'-phenylethyl)pyridinium chloride $(\mathbf{2 3})^{14}$. The data for the new compounds are:

(S)-(-)-1-[1'(2-chlorophenyl)ethyl]-3-ethylpyridinium chloride (16) ${ }^{1} \mathrm{H} \mathrm{NMR}\left(\mathrm{CDCl}_{3} 200 \mathrm{MHz}\right), \delta: 1.33(\mathrm{t}, J=7,5 \mathrm{~Hz}, 3 \mathrm{H}) ; 2.26$ (d, $J$ $=6,9 \mathrm{~Hz}, 3 \mathrm{H}) ; 2.97(\mathrm{q}, J=7,5 \mathrm{~Hz}, 2 \mathrm{H}) ; 6.77(\mathrm{q}, J=6.9 \mathrm{~Hz}, 1 \mathrm{H})$; 7.37-7.56 (m, $3 \mathrm{H}) ; 8.00$ (d, $J=7,3 \mathrm{~Hz}, 1 \mathrm{H}) ; 8.17(\mathrm{dd}, J=5.9 \mathrm{~Hz}$, $J=7.9 \mathrm{~Hz}, 1 \mathrm{H}) ; 8.32(\mathrm{~d}, J=7.9 \mathrm{~Hz}, 1 \mathrm{H}) ; 9,25(\mathrm{~d}, J=5.9 \mathrm{~Hz}, 1 \mathrm{H})$; 9.37 (s, $1 \mathrm{H})[\alpha]_{\mathrm{D}}:-69,9(\mathrm{c}=1.32-\mathrm{EtOH}) . \mathrm{IR}\left(\mathrm{cm}^{-1}\right)$ : 3350; 3050; $1660 ; 1630 ; 1500 ; 1475 ; 1450 ; 1390 ; 1260 ; 1200 ; 1140 ; 1040 ; 830$; 770; 750; 690 .

(S)-(-)-1-[1'(2-chlorophenyl)ethyl]-)-3-methylpyridinium chloride (19) ${ }^{1} \mathrm{H}$ NMR ( $\left.\mathrm{CDCl}_{3} 200 \mathrm{MHz}\right), \delta: 2.25$ (d, $\left.J=7.0 \mathrm{~Hz}, 3 \mathrm{H}\right) ; 2.64$ $(\mathrm{s}, 3 \mathrm{H}) ; 6.74(\mathrm{q}, J=7.0 \mathrm{~Hz}, 1 \mathrm{H}) ; 7.37-7.56(\mathrm{~m}, 3 \mathrm{H}) ; 8.00(\mathrm{~d}, J=$ $7.4 \mathrm{~Hz}, 1 \mathrm{H}) ; 8.13(\mathrm{dd}, J=6.2 \mathrm{~Hz}, J=7.8 \mathrm{~Hz}, 1 \mathrm{H}) ; 8.32(\mathrm{~d}, J=7.8$ $\mathrm{Hz}, 1 \mathrm{H}) ; 9.22(\mathrm{~d}, J=6.2 \mathrm{~Hz}, 1 \mathrm{H}) ; 9.42(\mathrm{~s}, 1 \mathrm{H}) \cdot{ }^{13} \mathrm{C} \operatorname{NMR}(50,3$ $\mathrm{MHz}, \mathrm{CDCl}_{3}$ ), $\delta$ (ppm): 18.6, 21.1, 67.7, 128.0, 128.1, 129.5, 130.3, $131.5,133.0,134.6,139.0,141.1,143.3,146.1 .[\alpha]_{D}:-19,2^{\circ}(c=1,14$ - EtOH). IR ( $\left.\mathrm{cm}^{-1}\right): 3350 ; 3050 ; 1660 ; 1630 ; 1500 ; 1475 ; 1450 ; 1390$; 1260; 1200; 1140; 1040; 830; 770; 750; 690 .

(S)-(-)-1-(1'-phenylethyl)-3-methylpyridinium dodecyl sulphate (22) ${ }^{1} \mathrm{H}$ NMR $\left(\mathrm{CDCl}_{3} 200 \mathrm{MHz}\right), \delta: 0.84-0.91(\mathrm{~m}, 3 \mathrm{H}) ; 1.23$ (s, $\left.18 \mathrm{H}\right)$; 1.53-1.64 (m, $2 \mathrm{H}) ; 2.52$ (s, $3 \mathrm{H}) ; 3.97$ [m, $3 \mathrm{H}] ; 4.29$ (dd, $J=4,1$ $\mathrm{Hz}, J=12,7 \mathrm{~Hz}, 1 \mathrm{H}) ; 4.54(\mathrm{dd}, J=9,7 \mathrm{~Hz}, J=12,7 \mathrm{~Hz}) ; 6.17$ (dd, $J=4,1 \mathrm{~Hz}, J=9.7 \mathrm{~Hz}, 1 \mathrm{H})$; 7.30-7.38 (m, $3 \mathrm{H}) ; 7.49-7.54$ (m, $2 \mathrm{H})$; $7.92(\mathrm{dd}, J=6.7 \mathrm{~Hz}, J=7.8 \mathrm{~Hz}, 1 \mathrm{H}) ; 8.11(\mathrm{~d}, J=7.8 \mathrm{~Hz}, 1 \mathrm{H}) ; 8.91$ $(\mathrm{s}, 1 \mathrm{H}) ; 8.92(\mathrm{~d}, J=6,7 \mathrm{~Hz}, 1 \mathrm{H}) \cdot{ }^{13} \mathrm{C} \mathrm{NMR}\left(50,3 \mathrm{MHz}, \mathrm{CDCl}_{3}\right), \delta$ 14.2, 18.7, 22.8, 25.9, 29.4, 29.6, 29.7, 32.0, 62.5, 68.1, 76.1, 127.9, $128.5,129.7,130.2,133.8,139.8,141.6,141.7,143.7,146.3$. IR $\left(\mathrm{cm}^{-1}\right): 3350 ; 3050 ; 1660 ; 1500 ; 1475 ; 1390 ; 1260 ; 1200 ; 1040 ; 830$; 770; 750; 690 .

\section{Natural products}

Leaves of Pilocarpus alatus were collected at Merck Co.'s farm, in Barra do Corda, Maranhão State, in the Northeast of Brazil. A voucher specimen (number 35148) was deposited at the Prisco Bezerra Herbarium (EAC), Universidade Federal do Ceará, Brazil.

The aqueous residue obtained after essential oil extraction of the leaves $(250.0 \mathrm{~g})$ from $P$. alatus was filtered and lyophilized, and yielded an aqueous extract, denominated extract 1 (31.0 g). An aliquot (4.8 g) of this extract was submitted to silica-gel column chromatography using a gradient mixture of ethyl acetate and methanol; it was then submitted to exclusion chromatography on Sephadex LH-20 using methanol as eluent and provided a mixture of gallocatechin (24) and 
epigallocatechin (25) (2:1) (22.0 mg) as well as the compound rutin (26) $(20.0 \mathrm{mg}$ ) (Figure 2). Extract 1 (31.0 g) was partitioned with ethyl acetate and yielded the extract $2(5.1 \mathrm{~g})$.

Leaves (400.0 g) of P. alatus were also extracted with hexane and then with ethanol providing hexane $(26.0 \mathrm{~g})$ and ethanolic extracts $(77.0 \mathrm{~g})$, respectively. An aliquot $(10.0 \mathrm{~g})$ of the ethanolic extract, denominated extract 3 , was chromatographed on silica gel by elution with hexane, chloroform, ethyl acetate, acetone and methanol. The methanol fraction was submitted to successive chromatographic processes allowing the isolation of hesperidin (27) (26.0 mg) (Figure 2). Structures of the isolated compounds were identified through ${ }^{1} \mathrm{H}$ and ${ }^{13} \mathrm{C}$ nuclear magnetic resonance (NMR) analysis, followed by literature comparison ${ }^{16-19}$.

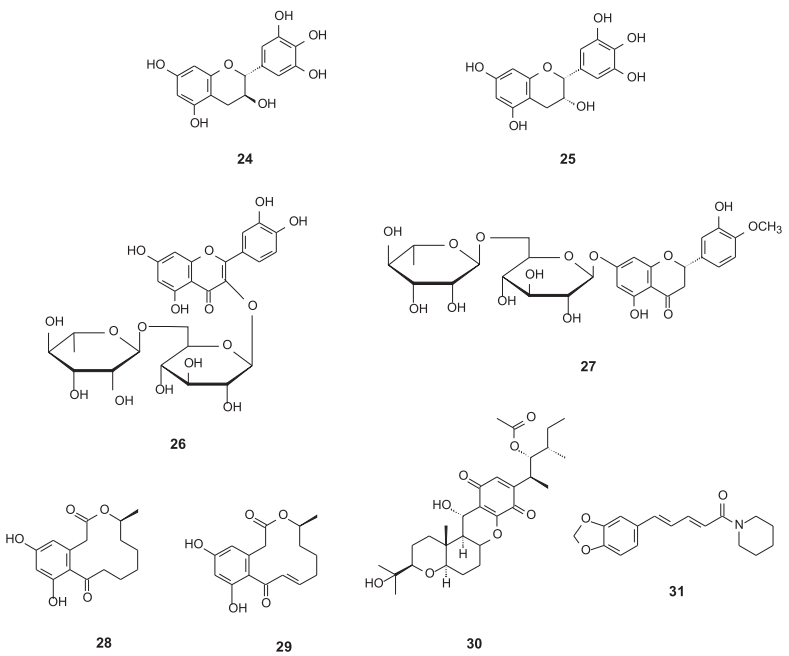

Figure 2. Structures of natural products evaluated on M. tuberculosis $H 37 R v$ : gallocatechin (24), epigallocatechin (25), rutin (26), hesperidin (27), curvularin (28), dihydrocurvularin (29), cochlioquinine A (30) and piperine (31).

Curvularin (28), dihydrocurvularin (29) and cochlioquinone A (30) were isolated from pure cultures of $C$. eragrostidis and $D$. dematioidea as previously described ${ }^{20}$. Floral resin of Clusia $s p$. rich in benzophenones was obtained as previously described ${ }^{21}$. Piperine (27) was isolated from black pepper (Piper nigrum) and identified as previously described ${ }^{22-24}$ (Figure 2).

\section{Antimycobacterial activity}

The antimycobacterial activity of the samples (compounds 1 8, 14-31, Clusia sp. floral resin, extract (2 and 3) was assayed in vitro against $M$. tuberculosis $\mathrm{H} 37 \mathrm{Rv}$ (ATCC 27294) using the microplate Alamar Blue assay ${ }^{25}$. Crude extracts, fractions or isolated compounds were dissolved in dimethylsulphoxide (DMSO) and serially diluted in Middlebrook $7 \mathrm{H} 9$ broth before inoculation. Concentrations used ranged from 0.5 to $1,000 \mu \mathrm{mol} / \mathrm{L}$ for isolated compounds and from 0.5 to $1.0 \mathrm{~g} / \mathrm{L}$ to crude extracts. The final concentration of DMSO in the assay was less than $0.3 \%$. Rifampicin was used as reference drug, and bioassays were performed in three independent experiments. The visual MIC were defined as the lowest drug concentration inhibiting mycobacterial growth and expressed by the average of the assays.

\section{Cytotoxicity}

The cytotoxic effect was assayed on J774 macrophages through the reduction of 3-(4,5-dimethylthiazole-2-yl)-2,5-diphenyl tetrazolium bromide (MTT) ${ }^{26,27}$. Stock solutions of N-(salicylidene)2-hydroxyaniline (2), curvularin (28), dihydrocurvularin (29) and Clusia sp. floral resin were prepared in DMSO and diluted in RPMI 1640 medium without phenol red. The final concentration of the solvent in the assay was less than $0.3 \%$. The controls received no drugs and each drug concentration was tested on six replicates, and repeated three times in separate experiments. Cells were exposed to the drugs at concentrations up to $1,000 \mu \mathrm{mol} / \mathrm{L}$ for isolated compounds (or 1,0 g/L in the case of Clusia sp. floral resin). The results are expressed by the cellular viability of the cells treated with the drugs and controls and $\mathrm{IC}_{50}$ was defined as the drug concentration required to reduce cellular viability by $50 \%$. The cytotoxicity was not evaluated on other sample.

Selectivity indexes $\left(\mathrm{SI}=\mathrm{IC}_{50} / \mathrm{MIC}\right)$ were calculated for $\mathrm{N}$ (salicylidene)-2-hydroxyaniline (2), curvularin (28), dihydrocurvularin (29), and Clusia sp. floral resin.

\section{RESULTS AND DISCUSSION}

The MICs were determined in vitro for M. tuberculosis H37Rv. The most effective compound among tested samples was $\mathrm{N}$ (salicylidene)-2-hydroxyaniline (2) with a MIC of $8 \mu \mathrm{mol} / \mathrm{L}$, followed by dihydrocurvularin (29), dihydrobenzoxazine (5), piperine (31), cochlioquinone A (30), N-(salicylidene)-4-toluidine (1), piperidine amide (6) and curvularin (28), which showed MIC of $40,250,250,250,500,500$ and $642 \mu \mathrm{mol} / \mathrm{L}$, respectively. Zincke's salts 14 and 15 showed MIC of 807 and $845 \mu \mathrm{mol} / \mathrm{L}$ and for Clusia sp. floral resin the MIC was $0.02 \mathrm{~g} / \mathrm{L}$.

Although ineffective on Aspergillus niger, Staphylococcus aureus and on Bacillus subtilis as previously reported ${ }^{20}$, dihydrocurvularin (29) was moderately effective on M. tuberculosis with MIC of $40 \mu \mathrm{mol} / \mathrm{L}$.

Previously, several pyridinium chlorides were evaluated in vitro by Pernak et al. ${ }^{4}$ on bacteria and fungi and the most active, 1undecyloxymethyl-3-(1-benzimidazolmethylamino) pyridinium chloride, $N, N$-bis[3-(1-decoxymethyl)pyridinium chloride]methylenediamine, 1-undecyloxymethyl-3-[1-(benzotriazol-1-yl)methylamino] pyridinium chloride, were tested against $M$. tuberculosis $\mathrm{H} 37 \mathrm{Rv}$ and showed a MIC of $14 \mu \mathrm{mol} / \mathrm{L}$. However, in this study, the antimycobacterial effect of pyridinium salts was shown to be weak. Pyridinium salt $\mathbf{2 3}$ showed a MIC of $1,000 \mu \mathrm{mol} / \mathrm{L}$ while compounds 16-22 were ineffective with MIC above 1,000 $\mu \mathrm{mol} / \mathrm{L}$. Similarly, cinnamylpiperazine (8) presented a MIC of $1,000 \mu \mathrm{mol} / \mathrm{L}$ and $\mathrm{N}$-(salicylidene)-4-aminobenzoic acid (3) and N-(salicylidene)4-nitroaniline (4) showed a MIC above 1,000 $\mu \mathrm{mol} / \mathrm{L}$.

Natural compounds, gallocatechin/epigallocatechin mixtures (2:1) (24 and 25), rutin (26) and hesperidin (27) were unable to inhibit mycobacteria growth at the tested concentrations of 38, 77 and $77 \mu \mathrm{mol} / \mathrm{L}$, respectively. The same effect was observed with extracts 2 and 3 at $0.125 \mathrm{~g} / \mathrm{L}$.

Due to their surfactant properties pyridinium salts can be absorbed by the bacterial cell surface, promoting lyses through interference with enzymes of the cell wall and membrane ${ }^{3}$. Although M. tuberculosis has a lipophilic membrane, pyridinium salts were ineffective, which suggests that the mechanistic pathways are not related to the cell wall and membrane.

The most effective synthetic compound on $M$. tuberculosis was $\mathrm{N}$-(salicylidene)-2-hydroxyaniline (2), and among the natural products Clusia $s p$. floral resin and dihydrocurvularin (29) were the most effective. It is interesting to note the presence of phenolic groups in all those most active compounds.

The cellular viability was evaluated through a cytotoxicity assay for $\mathrm{N}$-(salicylidene)-2-hydroxyaniline (2), curvularin (28), 
dihydrocurvularin (29), and Clusia sp. floral resin. The $\mathrm{IC}_{50}$ values were $>1,000,300$ and $30 \mu \mathrm{mol} / \mathrm{L}$ and $0.1 \mathrm{~g} / \mathrm{L}$, respectively. The cytotoxicity was not evaluated for other samples since they showed weak antimycobacterial activities with high MIC values.

Previous reports indicated that the drug's SI above 10 is an indication of its therapeutic safety and effectiveness for it to be a good candidate against tuberculosis. The SI values of $\mathrm{N}-$ (salicylidene)-2-hydroxyaniline (2), curvularin (28), dihydrocurvularin (29) and Clusia sp. floral resin are > 125.0, 0.47, 0.75 and 5.0, respectively. Compound $\mathbf{2}$ showed a weak cytotoxicity to J774 macrophages and at $1,000 \mu \mathrm{mol} / \mathrm{L} 80 \%$ of cells were viable indicating a higher selectivity of the drug to the pathogen than to the mammalian cells.

\section{CONCLUSIONS}

Among tested samples N-(salicylidene)-2-hydroxyaniline (2) was the most effective compound on M. tuberculosis H37Rv while showing a very weak cytotoxicity on J774 macrophages. Its SI is above 125.0 and at the tested concentration, an $\mathrm{IC}_{50}$ was not found $(\mathrm{SI}=>1,000 / 8)$. The results for this compound are indicative of the promising antimycobacterial activity of this molecule which, in a next step, will be tested on experimental tuberculosis.

\section{ACKNOWLEDGMENTS}

The authors thank the Conselho Nacional de Desenvolvimento Científico e Tecnológico (CNPq) for scholarship (PIBIC) to M. M. Parma and are grateful for the financial support to A. O. de Souza (Profix-CNPq). The authors also thank the Brazilian Tuberculosis Research Network (REDE TB-Instituto do Milênio).

\section{REFERENCES}

1. Tripathi, R. P.; Tewari, N.; Dwivedi, N.; Tiwari, V. K.; Med. Res. Rev. 2005 , $25,93$.

2. Donadio, S.; Monciardini, P.; Alduina, R.; Mazza, P.; Chiocchini, C.; Cavaletti, L.; Sosio, M.; Puglia, A. M.; J. Biotechnol. 2002, 99, 187.
3. Maeda, T.; Manabe, Y.; Yamamoto, M.; Yoshida, M.; Okazaki, K.; Nagamune, H.; Kourai, H.; Chem. Pharm. Bull. 1999, 47, 1020.

4. Pernak, J.; Kalewska, J.; Ksycinska, H.; Cybulski, J.; Eur. J. Med. Chem. 2001, 36, 899

5. De Souza, A. O.; Pedrosa, M. T.; Alderete, J. B.; Cruz, A. F.; Prado, M. A.; Alves, R. B.; Silva, C. L.; Pharmazie 2005, 60, 396.

6. De Souza, A. O.; Santos-Jr., R. R.; Sato, D. N.; De Azevedo, M. M. M.; Ferreira, D. A.; Melo, P. S.; Haun, M.; Silva, C. L.; Durán, N.; J. Antimicrob. Chemother. 2004, 50, 629.

7. Silva, C. L.; Bonato, V. L.; Coelho-Castelo, A. A.; De Souza, A. O.; Santos, S. A.; Lima, K. M.; Faccioli, L. H.; Rodrigues, J. M.; Gene Ther. 2005, 12, 281.

8. Iskander, M. N.; Andrews, P. R.; J. Chem. Educ. 1985, 62, 913.

9. Zheglova, D. K.; Gindin, V.; Koltsov, A. I.; J. Chem. Res. 1995, 1, 32.

10. Senier, A. I.; Shepeard, F. G.; J. Chem. Soc. 1909, 95, 1943.

11. Katritsky, A. R.; Ghiviriga, I.; Leeming, P.; Soti, F.; Magn. Reson. Chem. 1996, 34, 518.

12. Sloop, J. C.; J. Chem. Educ. 1995, 72, A25.

13. Genisson, Y.; Marazano, C.; Mehmandoust, M.; Gnecco, D.; Das, B.C.; Synlett 1992, 5, 431.

14. Diez, A.; Vilaseca, L.; López, I.; Rubiralta, M.; Heterocycles 1991, 32, 2139.

15. Viana, G. H. R.; Santos, I. C.; Alves, R. B.; Gil, L.; Marazano, C.; Gil, R. P. F.; Tetrahedron Lett. 2005, 45, 7773.

16. Gunasegaran, R.; Subramani, K.; Parimalaa, P. A.; Nair, A. G. R.; Rodriguez, B.; Madhusudanan, K. P.; Fitoterapia 2000, 72, 201.

17. Ferreira, D. T.; Alvares, P. S. M.; Houghtoun, P. J.; Braz-Filho, R.; Quim. Nova 2000, 23, 42.

18. Foo, L. Y.; Lu, Y.; Molan, A. L.; Woodfield, D. R.; Mcnabb, W. C.; Phytochemistry 2000, 54, 539 .

19. Markhan, K. R.; Ternai, B.; Stanley, R.; Geiger, H.; Mabry, T. J.; Tetrahedron 1978, 34, 1389

20. Bicalho, B.; Gonçalves, R. A. C.; Zibordi, A. P. M.; Manfio, G. P.; Marsaioli, A. J.; Z. Naturforsch, A: Phys. Sci. 2003, 58, 746.

21. Porto, A. L. M.; Machado, S. M. F.; de Oliveira, C. M. A.; Bittrich, V.; Amaral, M. E.; Marsaioli, A. J.; Phytochemistry 2000, 55, 755.

22. Epstein, W. W.; Netz, D. F.; Seidel, J. L.; J. Chem. Educ. 1993, 70, 598.

23. Ikan, R.; Natural Products - a laboratory guide, $2^{\text {nd }}$ ed, Academic Press: New York, 1991.

24. Wenkert, E.; Cochran, D. W.; Hagaman, E. W.; Lewis, R. B.; Shell, F. M.; J. Am. Chem. Soc. 1971, 93, 6271.

25. Collins, L. A.; Franzblau, S. G.; Antimicrob. Agents Chemother. 1997, 41, 1004.

26. De Souza, A. O.; Santos-Jr., R. R.; Sato, D. N.; De Azevedo, M. M. M.; Ferreira, D. A.; Melo, P. S.; Haun, M.; Silva, C. L.; Durán, N.; J. Braz. Chem. Soc. 2004, 15, 682 .

27. Denizot, F.; Lang, R; J. Immunol. Methods 1986, 89, 271. 